\title{
Government Size and Openness: Insights Based on Country Classificationsa
}

\author{
ERKAM SARI ${ }^{b}$ HaKAn HotunluoĞLU
}

Received: 15.04.2021; Revised: 19.05.2021; Accepted: 21.05.2021

This study investigates the nexus between government size and openness by paying special attention to country classification. The main results of our empirical investigations show that $(i)$ there are two government size trends meaning two different country groups exist; (ii) there is a positive relationship between trade openness and government size for the first country group, which validates the compensation hypothesis; (iii) a negative relationship between financial openness and government size is found for the second country group, which confirms the efficiency hypothesis; (iv) the effect of financial openness is nearly ten times higher than trade openness; $(v)$ an endogenous country classification process yields better results to understand the linkages between openness and government size. In this regard, our study incorporates both hypotheses and provides a uniform explanation.

JEL codes: C33, F62, H50

Keywords: Government size, Trade openness, Financial openness, Club convergence

\section{Introduction}

Higher economic integration embodies complex economic impacts on national economies. Either through the exchange of goods and services or financial flows, certain mechanisms such as international competition, demand for social protection, tax competition etc., emerge as a direct consequence. In this context, the role of and, more precisely, the size of government holds a major role in adapting and responding to economic integration. In his seminal work, Cameron (1978) asks "does trade openness increases government size?" linking to important aspects of economies. This question, however, only accounts for trade openness, i.e., one component of economic integration. Following the technological advancements in the telecommunication field, especially after the 1990s, financial openness increased drastically. Due to increased financial openness alongside trade openness, Cameron (1978)'s question has evolved into "does openness increase (decrease) government size?" accounting for both

\footnotetext{
a This research article is an extension of the first author's M.A. thesis, supervised by the second author. We thank the anonymous referees for their useful suggestions. Furthermore, we thank Prof. Dr. Etem Karakaya and Dr. Sedat Alataş for their insights and contributions.

b Corresponding author. Department of Public Finance, Nazilli Faculty of Economics and Administrative Sciences, Adnan Menderes University, Aydın, Turkey. email: erkam.sari@adu.edu.tr (D) https://orcid.org/0000-0001-5157-3173

c Department of Public Finance, Aydın Faculty of Economics, Adnan Menderes University, Aydın, Turkey. email: hakanhotunlu@gmail.com (D) https://orcid.org/0000-0002-2011-5978
} 
major components of economic integration.

Although the underlying question is fifty years old, the debate surrounding it is still ongoing with two competing hypotheses with contradictory results. The first hypothesis, i.e., the compensation hypothesis, argues that trade openness increases government size, while the second hypothesis, i.e., the efficiency hypothesis, argues that financial openness decreases government size. We argue that the main reason behind the lack of a consensus stems from a methodological inadequacy rather than an insufficient theoretical background. Under two competing hypotheses, shedding light on the debate without accounting for government size trends and using heterogeneous country samples would yield conflicting results, as shown in the literature section. In this context, our study differs from the rest of the literature by considering government size trends and heterogeneity by employing a club convergence methodology proposed by Phillips \& Sul (2007, 2009). Therefore, our study is also the first to employ the aforementioned methodology in the literature, thereby adding a major methodological contribution.

Using the club convergence results as a basis for country classification, we are then able to test both hypotheses for different country groups by paying attention to government size trends. We then apply pooled OLS and fixed-effects models to the country groups determined by the club convergence analysis. Our data consists of 71 countries and covers the years between 1971 and 2018. The results from the club convergence analysis show that there are two country groups. While the pooled OLS models fail to provide statistically significant results, fixed-effects models imply a positive relationship between trade openness and government size for the first country group and a negative relationship between financial openness and government size for the second country group.

The rest of the study is organized as follows. Section 2 explains the two main hypotheses in the literature and presents important determinants of government size. Section 3 provides the data and methodology in detail. Section 4 includes the empirical results and findings. Section 5 concludes.

\section{Literature Review and Theoretical Background}

Starting with Cameron (1978), the controversial topic of the relationship between government size and openness has been investigated intensively. Although Cameron (1978) mainly focused on the dynamics between industrial concentration, collective bargaining and political behaviors generated by trade openness, the author also emphasized the role of governments in compensating the risks of international trade. Following him, the topic of the relationship between government size and trade openness has evolved and, to an extent, diverged into an extensive field with studies ${ }^{1}$ (e.g. Islam, 2004; Benarroch \& Pandey, 2008; Epifani \& Gancia, 2009; Molana et al., 2011; Benarroch \& Pandey, 2012; Aydoğus \& Topcu, 2013; Liberati, 2013; Turan \& Karakaş, 2016; Fujii, 2017) investigating this relationship through different aspects ${ }^{2}$ and variables. Following the increase in capital flows between countries, others (Erauskin, 2011; Dixit, 2014; de Mendonça \& de Oliveira, 2019) have studied the impact of financial openness alongside trade openness. Two hypotheses, namely, the compensation and efficiency hypotheses, have emerged in the literature in order

${ }^{1}$ For a meta-analysis regarding the literature, please see Heimberger (2020).

${ }^{2}$ For instance, Arawatari (2015) developed a theoretical framework by using a Hecksher-Ohlin model. 
to explain certain dynamics between government size and openness.

According to the compensation hypothesis, trade openness and government size are positively related (Cameron, 1978; Ruggie, 1982; Rodrik, 1998). The argumentation is that as countries increase their level of international economic integration, the risk perception of individuals also tends to increase, which, in turn, results in higher demand for social protection expenditures. Additionally, countries with higher openness levels are more sensitive to international economic shocks. In order to suppress the negative effects of these shocks, governments will respond by increasing public spending, thus, decreasing output volatility. Furthermore, although economic integration is considered as a win-win scenario for the partners, there could be some disadvantaged groups at sectoral level. Therefore, to compensate for the losing side of economic integration, social protection spending will increase, which also increases the size of the government. Although the theoretical foundations of the compensation hypothesis are quite reasonable, studies (e.g., Balcells Ventura, 2006; Down, 2007; Kim, 2007; Hardiman et al., 2008; Walter, 2010; Martin \& Steiner, 2013; Lin et al., 2014; de Jongh, 2020) investigating the validity of this hypothesis have produced mixed results. The samples, methodologies and country classifications of these studies are presented in Table A.2 in the Appendix.

The second hypothesis is known as the efficiency hypothesis. This perspective on the issue argues that countries will decrease their government size and attract foreign investment to achieve economic growth (Garrett \& Mitchell, 1999; Garrett, 2001; Garrett \& Mitchell, 2001). The main assumption is that capital mobility is highly elastic to tax rates and government expenditures. The first part of the argument is an extension of the argument stating that capital flows will concentrate on countries with lower tax rates on investments and capital gains. This will force governments to lower tax rates and, as a result, a reduction in tax revenues will lead to a decrease in government size. The second part of the argument is that, apart from government expenditures that facilitate a better environment for private investments, capital flows prefer countries with smaller government sizes where public spending does not distort investment decisions. The validity of this hypothesis has also been tested by some studies (e.g., Kittel \& Winner, 2005; Gemmell et al., 2008; Kim, 2009; Leibrecht et al., 2011; Meinhard \& Potrafke, 2012; Bayat et al., 2017) and mixed results were obtained. Table A.2 in the Appendix presents the samples, methodologies and country classifications of these studies.

As discussed by Liberati (2007), both hypotheses should be investigated in the same context rather than focusing on only one aspect of the debate. Similar to Liberati (2007), Dreher et al. (2008) argued that both hypotheses could neutralize each other due to their contradictory structures. As a result, under heterogeneous country samples, the possibility of countries with different government size trends could impact the overall validity of the empirical results. Similar remarks have been put forward by Adam \& Kammas (2007), where they have validated both hypotheses.

Although the majority of the studies focused on either testing the compensation hypothesis or the efficiency hypothesis by using trade openness and financial openness, respectively, other major studies investigated the effects of country size or output volatility on government size by controlling for openness. Studies (e.g., Alesina \& Wacziarg, 1998; Ram, 2009; Jetter \& Parmeter, 2015; Sabra, 2016) analyzing the relationship between country size (measured by total population) and government size have also produced mixed results. The same holds true for the relationship between output volatility and government size (Virén, 2005; 
Bekaert et al., 2006; Andrés et al., 2008; Cavallo et al., 2008; Debrun et al., 2008; di Giovanni \& Levchenko, 2009; Collard et al., 2017).

The combined results of the literature are quite vague and yet to be understood. Our study argues that one of the main reasons behind the conflicting results of the studies on this issue is in the country selection criteria. Exogeneous country selection criteria, such as income, development, geography, or membership of an organization would yield biased or inconsistent results. From this aspect, our study has a major difference. Instead of exogenous variables, we use an endogenous process to determine country groups. This allows us to apply panel estimations on different country groups, where each country group includes countries with converging patterns of government size. The following section explains our reasoning behind the applied methodological process.

\section{Data and Methodology}

We obtained our data from World Development Indicators (WDI) for the years between 1971 and 2018. Penn World Tables (PWT) 9.1 was also considered as a source. However, due to the lack of foreign direct investment data in PWT, we had to choose WDI as our source for comparable and consistent analysis. Due to the limitations of WDI, the unbalanced data $^{3}$ of foreign direct investment (inflows), we use 1971 as the first year and drop some countries from the whole sample. As a result, 71 countries were used in the estimations.

We have used government final consumption expenditure-to-GDP ratio (GS), total trade volume-to-GDP ratio (TOpen), and foreign direct investment (inflows)-to-GDP ratio (FOpen) to represent government size, trade openness and financial openness, respectively. Although we are mainly interested in the relationship between trade openness and financial openness with government size, some studies (e.g., Alesina \& Wacziarg, 1998; Kim, 2007; Ram, 2009; di Giovanni \& Levchenko, 2009; Collard et al., 2017) have shown the importance of country size and output volatility. The logarithm of the total population represents the country size, while output volatility is calculated as the standard deviation of GDP growth. Our control variables are GDP (in logarithms) and age dependency ratio following Rodrik (1998). The abbreviations for country size, output volatility, GDP, and age dependency ratio are CSize, Vol, GDP and Adr, respectively.

Table 1: Summary Statistics

\begin{tabular}{|lcccc|}
\hline Variable & Mean & Std. Dev. & Min & Max \\
\hline Government Final Consumption Expenditure-to- & 15.63 & 5.65 & 1.98 & 61.07 \\
GDP, \% & & & & \\
Trade Volume-to-GDP, \% & 71.15 & 55.18 & 6.32 & 442.62 \\
Foreign Direct Investments (Inflows)-to-GDP, \% & 3.09 & 13.44 & -39.54 & 451.64 \\
Total Population (in logarithm) & 16.40 & 1.49 & 12.24 & 21.03 \\
GDP (constant USD 2010 prices, in logarithm) & 24.99 & 2.16 & 20.82 & 30.51 \\
Age Dependency Ratio, \% & 68.32 & 18.87 & 26.99 & 112.80 \\
\hline Note: The total number of observations is 3,408 for all variables. The values of GDP and total population are \\
in logarithms.
\end{tabular}

According to the summary statistics presented in Table 1 , the coefficients of variation for government size, trade openness and financial openness are $36 \%, 77 \%$ and $434 \%$, respec-

${ }^{3}$ In order to apply the Phillips and Sul club convergence approach, the structure of the data must be balanced. Therefore, certain countries and years were dropped from the main sample. 
tively. These values indicate that the level of dispersion of government size is the lowest, while financial openness has the highest level. Additionally, the range between the minimum and maximum values for government size, trade openness and financial openness implies low levels of uniformity for each variable.

Unless the main sample is disaggregated according to government size trends, the contradictory nature of these two mechanisms could interfere with each other. Table 2 presents mean values and correlation coefficients for selected country groups. Here, we observe that the sign and magnitude of the correlation coefficients seem independent of income levels and geographical locations. The different findings and contrast found in the literature could arise for this specific reason since studies in this field either focused on samples with ex-ante classification or heterogeneous samples without any classification.

Table 2: Mean Values and Correlation Coefficients of Country Groups Based on Geography and Income (1960-2020)

\begin{tabular}{|l|ccc|cc|}
\hline \multirow{2}{*}{ Country Classification } & \multicolumn{4}{|c|}{ Mean Values } & \multicolumn{2}{c|}{ Correlation Coefficient } \\
& GS (\%) & TOpen (\%) & FOpen (\%) & GS \& TOpen & GS \& FOpen \\
\hline Geographical & & & & & \\
Middle East and East Africa & 19.54 & 70.84 & 1.36 & -0.63 & -0.62 \\
Arab World & 19.30 & 76.25 & 1.24 & -0.59 & -0.30 \\
Europe and Central Asia & 19.09 & 61.18 & 2.39 & 0.65 & 0.24 \\
Central Europe and the Baltics & 18.66 & 99.01 & 3.02 & -0.74 & -0.04 \\
World & 16.37 & 45.10 & 1.70 & 0.80 & 0.50 \\
North America & 16.17 & 25.00 & 1.26 & -0.73 & -0.73 \\
East Asia and Pacific & 14.50 & 46.10 & 1.32 & 0.87 & 0.84 \\
Sub Saharan Africa & 12.90 & 49.99 & 1.46 & 0.63 & 0.69 \\
Latin America and Caribbean & 12.83 & 32.83 & 2.13 & 0.89 & 0.90 \\
South Asia & 9.98 & 25.41 & 0.72 & 0.21 & 0.18 \\
\hline Income Based & & & & & \\
High Income & 17.51 & 47.16 & 1.74 & 0.62 & 0.27 \\
Upper Middle Income & 13.45 & 35.28 & 1.78 & 0.87 & 0.77 \\
Middle Income & 13.02 & 36.00 & 1.65 & 0.87 & 0.78 \\
Low Income & 11.70 & 51.45 & 1.69 & 0.67 & 0.22 \\
Lower Middle Income & 11.22 & 38.98 & 1.22 & 0.20 & 0.21 \\
\hline
\end{tabular}

As mentioned in the literature section, this is the first study to our best knowledge to investigate the nexus between government size and openness by putting a special emphasis on country classification. The main reason behind classifying countries is that countries have drastic differences in terms of macroeconomic dynamics, which, in turn, dictate different government size trends. If we can classify countries according to their government size trends, then we can also investigate the main forces behind the trends separately. In order to classify countries according to government size trends, we applied the club convergence approach proposed by Phillips \& Sul $(2007,2009)$. There are two main advantages of this club convergence algorithm. Firstly, clustering countries endogenously by allowing for the possibility of transitional country heterogeneity ensures the negation of ex-ante sample classification. As a result, the method does not rely on year specifications and allows for time-varying behavior for the years covered in the sample. Secondly, it enables multiple equilibria to occur instead of a single steady-state of convergence. This is achieved by capturing different equilibria points for countries that diverge from the panel average. As a direct result, ex-ante country classifications based on income, development and geographical 
locations become unnecessary. Instead, the method solely relies upon the variable of interest itself. Using this method to classify countries is justified since cross-country heterogeneity is more likely to occur due to the progress of government size over time, instead of similar income and development levels, membership of an organization or geographical and regional determinants.

The Phillips and Sul club convergence method (PS thereafter) can be explained as,

$$
X_{i t}=\delta_{i t} \mu_{t}
$$

where $X_{i t}$ is the variable of interest and consists of two components for time $t$ at country $i$. The first component, $\delta_{i t}$, captures the time-varying idiosyncratic element of the equation and represents the deviation of a country from the common trend. The second component, $\mu_{t}$, on the other hand, represents the common trend. However, since $\delta_{i t}$ cannot be directly estimated, PS have rescaled the panel average by removing the common component, $\mu_{t}{ }^{4}$ This, in turn, allows the relative transition parameter, $h_{i t}$, to estimate $\delta_{i t}$ by relating it to the panel average as seen in Eq. (2).

$$
h_{i t}=\frac{X_{i t}}{\frac{1}{N} \sum_{i=1}^{N} X_{i t}}=\frac{\delta_{i t}}{\frac{1}{N} \sum_{i=1}^{N} \delta_{i t}}
$$

PS have also assumed a semiparametric model for $\delta_{i t}$ such as,

$$
\delta_{i t}=\delta_{i}+\sigma_{i t} \xi_{i t}
$$

where, $\sigma_{i t}$ is $\frac{\sigma_{i}}{L(t) t^{\alpha}}, L_{t} \rightarrow \infty, t \rightarrow \infty, \xi_{i t}$ is $i i d(0,1)$ across $i$ and $\delta_{i}$ is fixed. The most important aspect of Eq. (3) is the speed of convergence, $\alpha$, since $\delta_{i t}$ will converge to $\delta_{i}$ as long as $\alpha>0$. This form of $\delta_{i t}$ allows us to develop a null and alternative hypothesis of convergence as,

$$
\begin{aligned}
& H_{0}: \delta_{i}=\delta \text { and } \alpha \geq 0 \\
& H_{A}: \delta_{i} \neq \delta \text { for all } i \text { or } \alpha<0
\end{aligned}
$$

In order to test the null hypothesis, Eq. (5) is formed. This equation is also known as the $\log$ t-test.

$$
\log \left(\frac{H_{1}}{H_{t}}\right)-2 \log L(t)=\hat{a}+\hat{b} \log t+\hat{\mu}_{t}
$$

Here, $t=\left[r^{*} T\right],\left[r^{*} T+1\right],\left[r^{*} T+2\right], \ldots, T$ with $r>0, H_{1} / H_{t}$ is the cross-sectional variance ratio, and the estimated coefficient, $\hat{b}$, is equal to $2 \hat{a}$. Using a one-sided t-test of inequality with heteroskedasticity and autocorrelation consistent standard errors on $\hat{b}$ enables the test of the null hypothesis of convergence, i.e., $\alpha \geq 0$. Here, we focus on whether $t_{\hat{b}}<1.65$ or $t_{\hat{b}}>-1.65$, which is the PS method's reference value. Under the scenario of $t_{\hat{b}}<1.65$, the null hypothesis of convergence is rejected at the $5 \%$ significance level.

Following the $\log$ t-test, the data-driven algorithm developed by Phillips \& Sul (2007, 2009 ) is applied. This process consists of four steps and identifies the clubs within the whole sample. The first step orders countries according to their last observations. The underlying assumption behind this step is that if there is convergent behavior, it is more likely to emerge

${ }^{4}$ The application of the Phillips and Sul club convergence approach is presented in detail by Du (2017). 
in the latest period. The second step forms the core group by choosing the first $k$ highest countries for some $N>k \geq 2$. Establishing the size of the core group requires maximizing $t_{k}=t_{\left(G_{k}\right)}$ over $k$, where the log t-test is used. The third step forms a complementary group. Here, by adding one country at a time to the core group from this complementary group and using the log t-test, we determine if the newly added country is a part of this club or not. The fourth step forms a new group, including countries that failed to meet the criteria of the core group. The log t-test is used again to see if there is convergent behavior within the new group. If the t-statistic log t-test reveals convergence, then another club is formed. This process continues until there are no more countries to form a new club. Lastly, the log t-test is applied to clubs to test for possible merging amongst clubs.

After applying the Phillips and Sul club convergence approach, we then utilize the club convergence results as a base for country classification. ${ }^{5}$ Here, we split our data according to club memberships under the assumption that the number of clubs is more than one. Following this procedure, we then utilize pooled OLS and fixed-effects models to determine the underlying mechanisms for each country group separately. The main reason for utilizing fixed-effect models over random-effect models is that since we apply the club convergence approach proposed by Phillips \& Sul (2007, 2009), our country groups will have homogenous structures. In this case, where we have homogenous samples, fixed-effect models produce more robust results compared to random-effect models.

\section{Empirical Results}

\subsection{Results of Country Classification}

The $\log$ t-test and club convergence results are shown in Table A.1. The estimated coefficient of the $\log$ t-test is less than zero and statistically significant. Thus, the null hypothesis of panel convergence is rejected; the full sample is not converging and indicates the presence of clubs. The second step is to apply the data-driven PS algorithm, which identifies two clubs. The first and second club consists of 48 and 23 members, respectively.

There are several important findings of the club convergence results. Firstly, although the club convergence results seem to classify countries based on development levels, there are significant exceptions. Developing and least developed countries such as Bolivia, Madagascar, Niger and South Africa are included in the first club, which also includes the majority of developed countries. As for the exceptions in the second club, we observe that Ireland and Singapore have similar government size trends with developing and least developed countries. It is clear from these results that classifying countries according to their development levels is not sufficient, and there are major differences between countries in terms of government spending. As our results imply, countries with relatively lower income and development levels have the same government size trends as comparatively developed ones. The second finding is that government size trends are not affected by membership of an organization or geographical locations. Thirdly, the number of members in Club 1 is two times higher than that of in Club 2. This finding means that nearly $66 \%$ of countries have the same government size trend in the long term, and the trend is more dominant, compared to Club 2. Lastly, there are only two government size trends which is consistent with the

${ }^{5}$ Another study that uses the same club convergence approach to classify countries is Karakaya et al. (2021). 


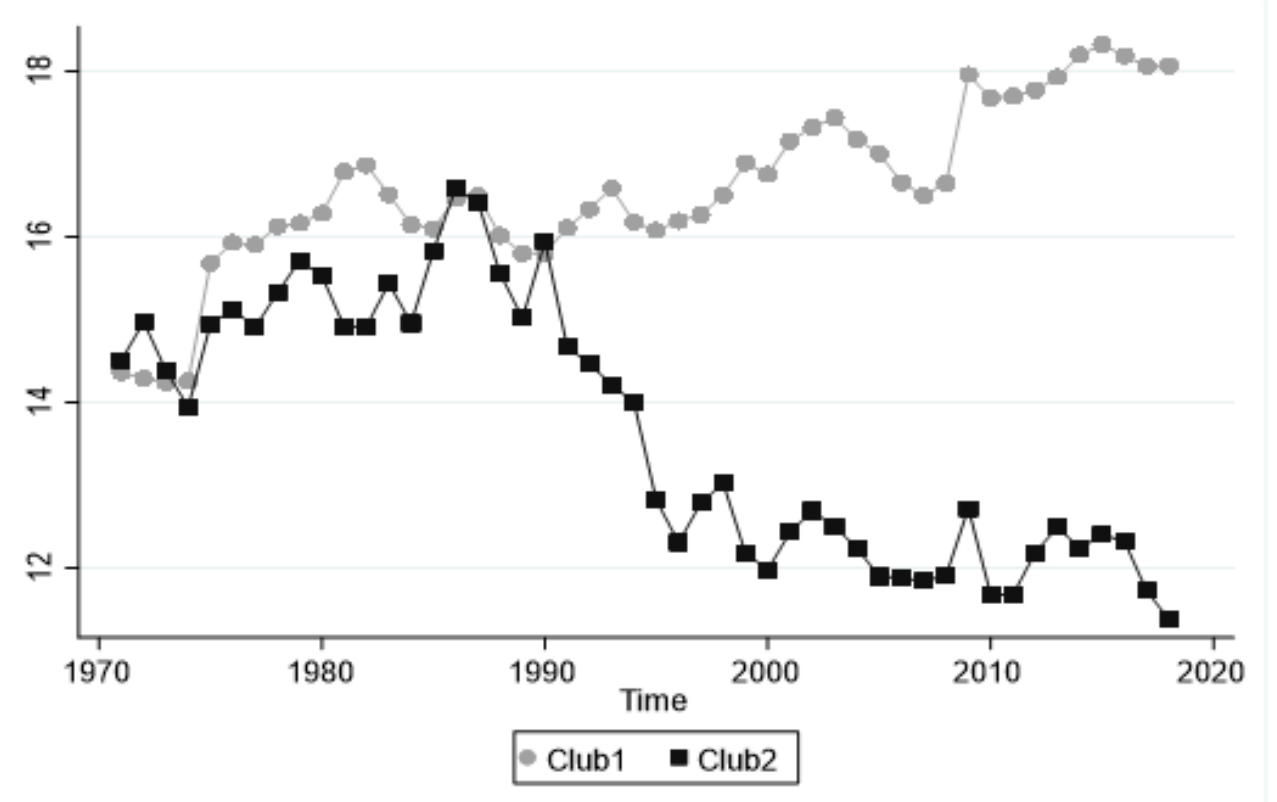

Figure 1: Government Size Trends of Clubs

theoretical foundations.

As mentioned earlier in the literature section, there are two main hypotheses for the relationship between openness and government size. Figure 1 presents valuable information with respect to these hypotheses as it illustrates diverging trends between Club 1 and Club 2 . Since the compensation hypothesis mainly argues that trade openness is positively and the efficiency hypothesis argues financial openness is negatively related to government size, it is reasonable to state that Figure 1 coincides with the theoretical background of the literature. According to the trends shown in Figure 1 and the theoretical argumentation, we expect to find a positive relationship between trade openness and government size for Club 1, and a negative relationship between financial openness and government size for Club 2.

Furthermore, Figure 1 also shows a structural change after 1990. While the government size has an increasing trend for Club 1, it has a drastically decreasing trend between 1990 and 2000 for Club 2. This could be explained by the rapid financialization process (Kimakova, 2009) after the 1990s. These divergent trends also indicate that the intensity of the two hypotheses differs from each other. The government size for Club 1 increased to $18 \%$ from $16 \%$, while it decreased to $12 \%$ from $16 \%$ for Club 2 . Here, we can argue that financial openness has a more intense effect on government size compared to trade openness, which, in turn, allows us to expect higher estimated coefficients for financial openness.

\subsection{Results of Panel Estimations}

In order to understand how openness is related to government size by paying special attention to country groups, we employ pooled OLS and fixed-effects models for each country group. The yearly data was transformed into 5-year intervals with the exception of the years between 2016 and 2018, which were transformed into a 3-year interval. As a result 
of this transformation, our time intervals start with 1971-1975 and end with 2016-2018. This transformation is necessary to avoid the distortionary effects of business cycles on the results. Additionally, as governments plan public spending through mid-term and long-term

Table 3: Estimated Coefficients of Trade and Financial Openness

\begin{tabular}{|c|c|c|c|c|c|c|c|c|}
\hline \multicolumn{9}{|c|}{ Dependent Variable: Government Size } \\
\hline Variable & Method & Sample & Model 1 & Model 2 & Model 3 & Model 4 & Model 5 & Model 6 \\
\hline \multirow{6}{*}{ Topen } & \multirow{3}{*}{ Pooled OLS } & Whole & $\begin{array}{c}-0.0148^{* * *} * \\
(0.0036)\end{array}$ & $\begin{array}{c}-0.00822^{* *} \\
(0.0038)\end{array}$ & $\begin{array}{c}0.0012 \\
(0.0038)\end{array}$ & & & \\
\hline & & Club 1 & $\begin{array}{c}-0.0036 \\
(0.0080)\end{array}$ & $\begin{array}{l}0.00415 \\
(0.0082)\end{array}$ & $\begin{array}{l}0.00868 \\
(0.0068)\end{array}$ & & & \\
\hline & & Club 2 & $\begin{array}{c}-0.00311 \\
(0.0048)\end{array}$ & $\begin{array}{c}-0.00825^{*} \\
(0.0045)\end{array}$ & $\begin{array}{c}-0.00177 \\
(0.0032)\end{array}$ & & & \\
\hline & \multirow{3}{*}{ Fixed-Effects } & Whole & $\begin{array}{c}0.00926 \\
(0.0081)\end{array}$ & $\begin{array}{l}0.0176^{*} \\
(0.0093)\end{array}$ & $\begin{array}{c}0.0114 \\
(0.0071)\end{array}$ & & & \\
\hline & & Club 1 & $\begin{array}{c}0.0109 \\
(0.0095)\end{array}$ & $\begin{array}{c}0.0182^{* *} \\
(0.0085)\end{array}$ & $\begin{array}{c}0.0263^{* * *} \\
(0.0069)\end{array}$ & & & \\
\hline & & Club 2 & $\begin{array}{c}0.0128 \\
(0.0188)\end{array}$ & $\begin{array}{c}0.00999 \\
(0.0200)\end{array}$ & $\begin{array}{c}-0.0269^{* *} \\
(0.0120)\end{array}$ & & & \\
\hline \multirow{6}{*}{ Fopen } & \multirow{3}{*}{ Pooled OLS } & Whole & $\begin{array}{l}0.00153 \\
(0.0119)\end{array}$ & $\begin{array}{l}0.00347 \\
(0.0117)\end{array}$ & & $\begin{array}{c}0.00828 \\
(0.0119)\end{array}$ & & \\
\hline & & Club 1 & $\begin{array}{l}-0.00692 \\
(0.0124)\end{array}$ & $\begin{array}{l}-0.00577 \\
(0.0133)\end{array}$ & & $\begin{array}{c}0.0136 \\
(0.0101)\end{array}$ & & \\
\hline & & Club 2 & $\begin{array}{c}-0.0829 \\
(0.0625)\end{array}$ & $\begin{array}{c}-0.1 \\
(0.0736)\end{array}$ & & $\begin{array}{c}-0.0798 \\
(0.0528)\end{array}$ & & \\
\hline & \multirow{3}{*}{ Fixed-Effects } & Whole & $\begin{array}{c}-0.0139 \\
(0.0188)\end{array}$ & $\begin{array}{c}-0.013 \\
(0.0178)\end{array}$ & & $\begin{array}{c}-0.00219 \\
(0.0149)\end{array}$ & & \\
\hline & & Club 1 & $\begin{array}{l}-0.00579 \\
(0.0099)\end{array}$ & $\begin{array}{l}-0.00537 \\
(0.0092)\end{array}$ & & $\begin{array}{c}0.0162^{* *} \\
(0.0071)\end{array}$ & & \\
\hline & & Club 2 & $\begin{array}{c}-0.183^{* *} \\
(0.0816)\end{array}$ & $\begin{array}{c}-0.182^{* *} \\
(0.087)\end{array}$ & & $\begin{array}{c}-0.277^{* *} \\
(0.104)\end{array}$ & & \\
\hline \multirow{6}{*}{ Volatility } & \multirow{3}{*}{ Pooled OLS } & Whole & $\begin{array}{c}-0.101 \\
(0.0744)\end{array}$ & $\begin{array}{c}-0.276^{* * *} \\
(0.0741)\end{array}$ & & & $\begin{array}{c}-0.155^{* *} \\
(0.0724)\end{array}$ & \\
\hline & & Club 1 & $\begin{array}{l}-0.0641 \\
(0.116)\end{array}$ & $\begin{array}{c}0.387^{* * *} \\
(0.128)\end{array}$ & & & $\begin{array}{c}-0.359^{* * *} \\
(0.121)\end{array}$ & \\
\hline & & Club 2 & $\begin{array}{l}-0.0825 \\
(0.0911) \\
\end{array}$ & $\begin{array}{c}-0.0288 \\
(0.0946) \\
\end{array}$ & & & $\begin{array}{c}0.266^{* *} \\
(0.107) \\
\end{array}$ & \\
\hline & \multirow{3}{*}{ Fixed-Effects } & Whole & $\begin{array}{c}-0.0679 \\
(0.051)\end{array}$ & $\begin{array}{l}-0.0699 \\
(0.0498)\end{array}$ & & & $\begin{array}{c}-0.0243 \\
(0.0479)\end{array}$ & \\
\hline & & Club 1 & $\begin{array}{c}-0.0232 \\
(0.0572)\end{array}$ & $\begin{array}{l}-0.0363 \\
(0.0542)\end{array}$ & & & $\begin{array}{c}-0.175^{* *} \\
(0.076)\end{array}$ & \\
\hline & & Club 2 & $\begin{array}{l}-0.0787 \\
(0.113)\end{array}$ & $\begin{array}{c}-0.0363 \\
(0.0996)\end{array}$ & & & $\begin{array}{l}0.141^{* *} \\
(0.0595)\end{array}$ & \\
\hline \multirow{6}{*}{$\begin{array}{l}\text { Country } \\
\text { Size }\end{array}$} & \multirow{3}{*}{ Pooled OLS } & Whole & $\begin{array}{c}-3.096^{* * *} \\
(0.203)\end{array}$ & $\begin{array}{c}-0.892^{* * *} \\
(0.146)\end{array}$ & & & & $\begin{array}{c}-0.677^{* * *} * \\
(0.127)\end{array}$ \\
\hline & & Club 1 & $\begin{array}{c}-2.998^{* * *} \\
(0.286)\end{array}$ & $\begin{array}{c}-0.362^{* *} \\
(0.175)\end{array}$ & & & & $\begin{array}{c}-0.346^{* *} \\
(0.136)\end{array}$ \\
\hline & & Club 2 & $\begin{array}{c}-2.365^{* * *} \\
(0.44)\end{array}$ & $\begin{array}{c}-1.429^{* * *} \\
(0.277)\end{array}$ & & & & $\begin{array}{c}-1.231^{* * *} \\
(0.23)\end{array}$ \\
\hline & \multirow{3}{*}{ Fixed-Effects } & Whole & $\begin{array}{l}-2.893 \\
(2.268)\end{array}$ & $\begin{array}{l}-1.099 \\
(1.275)\end{array}$ & & & & $\begin{array}{c}-0.578 \\
(1.116)\end{array}$ \\
\hline & & Club 1 & $\begin{array}{c}1.004 \\
(2.059)\end{array}$ & $\begin{array}{l}2.523^{*} \\
(1.305)\end{array}$ & & & & $\begin{array}{c}3.141^{* * *} \\
(1.115)\end{array}$ \\
\hline & & Club 2 & $\begin{array}{l}-4.579 \\
(3.39)\end{array}$ & $\begin{array}{l}-3.300^{*} \\
(1.786)\end{array}$ & & & & $\begin{array}{c}-3.847^{* *} \\
(1.617)\end{array}$ \\
\hline
\end{tabular}

Note: Robust standard errors in parentheses. ${ }^{* *},{ }^{* *}$, and $*$ stand for $1 \%, 5 \%$, and $10 \%$ significance level, respectively. 
development goals, using 5-year averages also encapsulates such progress plans, which includes expenses such as social protection and economic affairs.

For both pooled OLS and fixed-effects models, six regressions were estimated. Model (1) includes all variables, i.e., TOpen, FOpen, Vol, CSize, GDP and Adr. Model (2) drops the control variables GDP and Adr. Model (3) includes only TOpen, whereas Model (4) is regressed using only FOpen. As for Model (5) and Model (6), they also include only one variable, i.e., Vol and CSize, respectively. Table 3 presents the estimated coefficients for TOpen, FOpen, Vol and CSize.

According to Table 3, the pooled OLS results for the whole sample indicate that trade openness is negatively related to government size, while the coefficients for financial openness are statistically insignificant. Focusing on the samples of Club 1 and Club 2, we also observe that pooled OLS models fail to produce statistically significant results. However, these results must be approached with suspicion because, firstly, the pooled OLS and fixed-effect results for the whole sample contain counter tendencies due to two competing government size trends. As mentioned earlier, Liberati (2007), Adam \& Kammas (2007) and Dreher et al. (2008) have emphasized that, these counter tendencies could neutralize each other. Secondly, pooled OLS models are not consistent as fixed-effect models when there is unobserved heterogeneity and, also, fail to capture individual heterogeneity.

Our fixed-effect results for the whole sample show statistically insignificant results as well. However, it is observed that trade openness is positively related to government size for Club 1, while financial openness is negatively related to government size for Club 2. Compared to pooled OLS results, fixed-effect results provide higher levels of significance. Overall, these results are in line with Liberati (2007); Epifani \& Gancia (2009); Erauskin (2011) and Lin et al. (2014).

As for the volatility and country size variables, the whole sample results of pooled OLS models imply a negative relationship with government size for both variables, while fixedeffect models do not provide any evidence. Focusing on Club 1, it is observed that there is partial support for a negative relationship between volatility and government size. Additionally, the coefficients of country size for Club 1 differs across pooled OLS and fixed-effect models; therefore, it is not possible to make a conclusion. For Club 2, there is partial support for a positive relationship between volatility and government size. Moreover, the pooled OLS and fixed-effect models both imply a negative relationship between country size and government size for Club 2 and support previous studies such as Alesina \& Wacziarg (1998) and Jetter \& Parmeter (2015).

The general conclusion from these results is that there seems to be a positive relationship between trade openness and government size for Club 1, while also there seems to be a negative relationship between financial openness and government size for Club 2. To test these observations, we have estimated several models. For both country clubs, six models were estimated. The models are given below, where Model (1) is represented by Eq. (6) and Model (6) is represented by Eq. (11). Here, $i=1, \ldots, N$ and $t=1, \ldots, T$, while $\beta_{0}$ is the intercept and $\mu$ is the error term.

$$
\begin{gathered}
\text { GSize }_{i t}=\beta_{0}+\beta_{1} T(F) \text { Open }_{i t}+\beta_{2} F(T) \text { Open }_{i t}+\beta_{3} \text { Vol }_{i t}+\beta_{4} \text { CSize }_{i t}+ \\
\beta_{5} G D P_{i t}+\beta_{6} A d r_{i t}+\mu_{i t}
\end{gathered}
$$




$$
\begin{aligned}
& \text { GSize }_{i t}=\beta_{0}+\beta_{1} T(F) \text { Open }_{i t}+\beta_{2} F(T) \text { Open }_{i t}+\beta_{3} \text { Vol }_{i t}+\beta_{4} \text { CSize }_{i t}+ \\
& \beta_{5} G D P_{i t}+\mu_{i t} \\
& \text { GSize }_{i t}=\beta_{0}+\beta_{1} T(F) \text { Open }_{i t}+\beta_{2} F(T) \text { Open }_{i t}+\beta_{3} \text { Vol }_{i t}+ \\
& \beta_{4} \text { CSize }_{i t}+\mu_{i t} \\
& \text { GSize }_{i t}=\beta_{0}+\beta_{1} T(F) \text { Open }_{i t}+\beta_{2} F(T) \text { Open }_{i t}+\beta_{3} V_{o l}+\mu_{i t} \\
& \text { GSize }_{i t}=\beta_{0}+\beta_{1} T(F) \text { Open }_{i t}+\beta_{2} F(T) \text { Open }_{i t}+\mu_{i t} \\
& \text { GSize }_{i t}=\beta_{0}+\beta_{1} T(F) \text { Open }_{i t}+\mu_{i t}
\end{aligned}
$$

\begin{tabular}{|c|c|c|c|c|c|c|c|}
\hline Sample & Variables & Model 1 & Model 2 & Model 3 & Model 4 & Model 5 & Model 6 \\
\hline \multirow{2}{*}{ Club 1} & TOpen & $\begin{array}{c}0.0109 \\
(0.0095)\end{array}$ & $\begin{array}{c}0.0176^{* *} \\
(0.0077)\end{array}$ & $\begin{array}{c}0.0182^{* *} \\
(0.0085)\end{array}$ & $\begin{array}{c}0.0258^{* * *} \\
(0.0076)\end{array}$ & $\begin{array}{c}0.0273^{* * *} \\
(0.0076)\end{array}$ & $\begin{array}{c}0.0263^{* * *} \\
(0.0069)\end{array}$ \\
\hline & FOpen & $\begin{array}{c}-0.0058 \\
(0.0099)\end{array}$ & $\begin{array}{l}-0.0053 \\
(0.0092)\end{array}$ & $\begin{array}{c}-0.0054 \\
(0.0092)\end{array}$ & $\begin{array}{l}-0.0051 \\
(0.008)\end{array}$ & $\begin{array}{l}-0.0051 \\
(0.0076)\end{array}$ & \\
\hline \multirow{2}{*}{ Club 2} & TOpen & $\begin{array}{c}0.0128 \\
(0.0188)\end{array}$ & $\begin{array}{c}0.0187 \\
(0.0207)\end{array}$ & $\begin{array}{c}0.0100 \\
(0.02)\end{array}$ & $\begin{array}{c}0.0007 \\
(0.0196)\end{array}$ & $\begin{array}{c}0.0023 \\
(0.0193)\end{array}$ & \\
\hline & FOpen & $\begin{array}{c}-0.183^{* *} \\
(0.0816)\end{array}$ & $\begin{array}{c}-0.174^{* *} \\
(0.0838)\end{array}$ & $\begin{array}{c}-0.182^{* *} \\
(0.087)\end{array}$ & $\begin{array}{c}-0.276^{* *} \\
(0.131)\end{array}$ & $\begin{array}{c}-0.283^{* *} \\
(0.135)\end{array}$ & $\begin{array}{c}-0.277^{* *} \\
(0.104)\end{array}$ \\
\hline
\end{tabular}

This process allows us to obtain better insights regarding interactions between openness and government size. The results are shown in Table 4 .

Table 4: Additional Regressions for Trade and Financial Openness

According to the results presented in Table 4, for Club 1, trade openness is positively related to government size in all models except for Model (1). However, there is no indication of a relationship regarding financial openness for Club 1. As for Club 2, as opposed to Club 1 , there is a negative relationship between financial openness and government size in all models, whereas trade openness is not statistically significant. Moreover, in almost all models, the coefficients of financial openness are approximately ten times higher than the coefficients of trade openness. This shows that the intensity of financialization puts more pressure on some countries and, as a result, the effect of trade openness diminishes.

Considering all the results together, we observe an apparent difference between Club 1 and Club 2. The results for Club 1 provide strong support for a positive relationship between trade openness and government size. On the contrary, the results for Club 2 indicates a robust negative relationship between financial openness and government size. These findings are in line with the results presented in Figure 1. Furthermore, although trade openness is more prevalent in most countries, the intensity of financial openness is higher than trade openness. These results prove our emphasis on using club convergence to classify countries according to their government size trends.

\section{Conclusions}

In this study, we have investigated the two main hypotheses regarding the nexus of government size and openness. However, we have put a special emphasis on country clas- 
sifications, where we have divided our sample according to trends in government sizes. According to our results, there is a crucial difference regarding the dynamics of government size. Firstly, we have found two country groups with diverging government size trends. The first country group includes the vast majority of developed countries, although developing and least developed countries with the same government size patterns are also within the first group. The second group mostly consists of developing and undeveloped countries. These results highlight the importance of classifying countries according to their government size trends rather than ex-ante classifications such as income and development levels, geographical locations, or membership of an organization. Secondly, there is a positive relationship between trade openness and government size for the first country group. This result validates the compensation hypothesis and shows that governments respond to higher trade openness with more public spending to compensate for the negative effects of economic integration and external economic shocks. Thirdly, for the second country group, we found a negative relationship between financial openness and government size. According to this result, we also validate the efficiency hypothesis, which indicates that some countries reduce tax rates and public spending due to tax competition and the negative response of capital mobility to distortionary public spending. Fourthly, the impact of trade openness is observed for the majority of countries in our sample; however, financial openness has a bigger impact on countries as the intensity of financialization is higher. As a result, this study incorporates both hypotheses in the same context. From this perspective, economic integration is a complex process that includes the dynamics of both the compensation and efficiency hypotheses. Depending on countries idiosyncratic characteristics, either trade or financial openness has the potential to suppress the other. Further research could focus on the intensity aspect of the issue. In this regard, determining which factors elevate one effect while also suppressing the other one could be a major contribution to the overall debate.

\section{References}

Adam, A., \& Kammas, P. (2007). Tax Policies in a Globalized World: Is it Politics After All? Public Choice, 133(3-4), 321-41. doi:10.1007/s11127-007-9190-9

Alesina, A., \& Wacziarg, R. (1998). Openness, Country Size and Government. Journal of Public Economics, 69(3), 305-21. doi:10.1016/S0047-2727(98)00010-3

Andrés, J., Doménech, R., \& Fatás, A. (2008). The Stabilizing Role of Government Size. Journal of Economic Dynamics and Control, 32(2), 571-93. doi:10.1016/j.jedc.2007.02.006

Arawatari, R. (2015). Political Economy of Trade Openness and Government Size. Economics \&6 Politics, 27(1), 28-52. doi:10.1111/ecpo.12049

Aydoğuş, I., \& Topcu, M. (2013). An Investigation of Co-integration and Causality between Trade Openness and Government Size in Turkey. International Journal of Economics and Financial Issues, 3(2), 319-23.

Balcells Ventura, L. (2006). Trade Openness and Preferences for Redistribution: A CrossNational Assessment of the Compensation Hypothesis. Business and Politics, 8(2), 1-50. doi:10.2202/1469-3569.1131 
Bayat, T., Taşar, I., \& Kayhan, S. (2017). The Validity of Efficiency and Compensation Hypothesis for G7 Countries. Ecoforum Journal, 6(2), 1-7.

Bekaert, G., Harvey, C. R., \& Lundblad, C. (2006). Growth Volatility and Financial Liberalization. Journal of International Money and Finances, 25(3), 370-403. doi:10.1016/j.jimonfin.2006.01.003

Benarroch, M., \& Pandey, M. (2008). Trade Openness and Government Size. Economics Letters, $101(3)$, 157-59. doi:10.1016/j.econlet.2008.06.016

Benarroch, M., \& Pandey, M. (2012). The Relationship between Trade Openness and Government Size: Does Disaggregating Government Expenditure Matter? Journal of Macroeconomics, 34(1), 239-52. doi:10.1016/j.jmacro.2011.11.002

Cameron, D. R. (1978). The Expansion of the Public Economy: A Comparative Analysis. The American Political Science Review, 72(4), 1243-61. doi:10.2307/1954537

Cavallo, E. A., de Gregorio, J., \& Loayza, N. V. (2008). Output Volatility and Openness to Trade: A Reassessment [with comments]. Economia, 9(1), 105-52.

Collard, F., Dellas, H., \& Tavlas, G. (2017). Government Size and Macroeconomic Volatility. Economica, 84(336), 797-819. doi:10.1111/ecca.12223

Debrun, X., Pisani-Ferry, J., \& Sapir, A. (2008). Government Size and Output Volatility: Should We Foresake Automatic Stabilisation? (Working Papers No. 2008/01). Bruegel.

de Jongh, J. (2020). Economic Globalisation and Government Size: Testing the Compensation Hypothesis in South Africa's Public Sector. International Journal of Business and Management Studies, 12(1), 66-83.

de Mendonça, H. F., \& de Oliveira, A. J. (2019). Openness and Government Size: A New Empirical Assessment. Economics Bulletin, 39(2), 982-95.

di Giovanni, J., \& Levchenko, A. (2009). Trade Openness and Volatility. The Review of Economics and Statistics, $91(3), 558-85$. doi:10.1162/rest.91.3.558

Dixit, V. (2014). Relation between Trade Openness, Capital Openness and Government Size in India: An Application of Bounds Testing-ARDL Approach to Co-integration. Foreign Trade Review, 49(1), 1-29. doi:10.1177/0015732513515987

Down, I. (2007). Trade Openness, Country Size and Economic Volatility: The Compensation Hypothesis Revisited. Business and Politics, 9(2), 1-20. doi:10.2202/1469-3569.1201

Dreher, A., Sturm, J. E., \& Ursprung, H. W. (2008). The Impact of Globalization on the Composition of Government Expenditures: Evidence from Panel Data. Public Choice, 134(3-4), 263-92. doi:10.1007/s11127-007-9223-4

Du, K. (2017). Econometric Convergence Test and Club Clustering using Stata. The Stata Journal, 17(4), 882-900. doi:10.1177/1536867X1801700407

Epifani, P., \& Gancia, G. (2009). Openness, Government Size and the Terms of Trade. The Review of Economic Studies, 76(2), 629-68. doi:10.1111/j.1467-937X.2009.00546.x

Erauskin, I. (2011). Financial Openness, Volatility, and the Size of Productive Government. SERIEs, 2(2), 233-53. doi:10.1007/s13209-010-0029-0

Fujii, E. (2017). Government Size, Trade Openness, and Output Volatility: A Case of Fully Integrated Economies. Open Economies Review, 28(4), 661-84. doi:10.1007/s11079-017$9433-4$ 
Garrett, G. (2001). Globalization and Government Spending around the World. Studies in Comparative International Development, 35(4), 3-29. doi:10.1007/BF02732706

Garrett, G., \& Mitchell, D. (1999). Globalization and the Welfare State. Yale: Leitner Program.

Garrett, G., \& Mitchell, D. (2001). Globalization, Government Spending and Taxation in the OECD. European Journal of Political Research, 39(2), 145-77. doi:10.1023/A:1011043120145

Gemmell, N., Kneller, R., \& Sanz, I. (2008). Foreign Investment, International Trade and the Size and Structure of Public Expenditures. European Journal of Political Economy, 24(1), 151-71. doi:10.1016/j.ejpoleco.2007.06.004

Hardiman, N., Murphy, P., \& Burke, O. (2008). The Politics of Economic Adjustment in a Liberal Market Economy: The Social Compensation Hypothesis Revisited. Irish Political Studies, 23(4), 599-626. doi:10.1080/07907180802452838

Heimberger, P. (2020). Does Economic Globalization Affect Government Spending? A Meta-analysis. Public Choice, 1-26. doi:10.1007/s11127-020-00784-8

Islam, M. Q. (2004). The Long run Relationship between Openness and Government Size: Evidence from Bounds Test. Applied Economics, 36(9), 995-1000. doi:10.1080/0003684042000233221

Jetter, M., \& Parmeter, C. F. (2015). Trade Openness and Bigger Governments: The Role of Country Size Revisited. European Journal of Political Economy, 37, 49-63. doi:10.1016/j.ejpoleco.2014.11.001

Karakaya, E., Sarı, E., \& Alataş, S. (2021). What Drives Material Use in the EU? Evidence from Club Convergence and Decomposition Analysis on Domestic Material Consumption and Material Footprint. Resources Policy, 70. doi:10.1016/j.resourpol.2020.101904

Kim, S. Y. (2007). Openness, External Risk, and Volatility: Implications for the Compensation Hypothesis. International Organization, 61(1), 181--216. doi:10.1017/S0020818307070051

Kim, T. K. (2009). Globalization and State-supported Welfare: A Test of the Curvelinear Hypothesis in OECD Countries. International Social Work, 52(2), 209-22. doi:10.1177/0020872808099731

Kimakova, A. (2009). Government Size and Openness Revisited: The Case of Financial Globalization. Kyklos, 62(3), 394-406. doi:10.1111/j.1467-6435.2009.00442.x

Kittel, B., \& Winner, H. (2005). How Reliable is Pooled Analysis in Political Economy? The Globalization-welfare State Nexus Revisited. European Journal of Political Research, 44(2), 269-93. doi:10.1111/j.1475-6765.2005.00228.x

Leibrecht, M., Klien, M., \& Onaran, O. (2011). Globalization, Welfare Regimes and Social Protection Expenditures in Western and Eastern European Countries. Public Choice, 148(3-4), 569-94. doi:10.1007/s11127-010-9685-7

Liberati, P. (2007). Trade Openness, Capital Openness and Government Size. Journal of Public Policy, 27(2), 215-47. doi:10.1017/S0143814X07000670

Liberati, P. (2013). Government Size and Trade Openness: Some Additional Insights (MPRA Paper No. 43561). University Library of Munich, Germany. 
Lin, F., Li, B., \& Sim, N. C. (2014). Trade Openness and Government Size of Small Developing Countries: An Instrumental Approach. Economics of Transition, 22(4), 783808. doi:10.1111/ecot.12053

Martin, C. W., \& Steiner, N. D. (2013). Public Spending and Trade Liberalization: The Compensation Hypothesis Revisited (Working Paper No. 2245595). SSRN. doi:10.2139/ssrn.2245595

Meinhard, S., \& Potrafke, N. (2012). The Globalization-welfare State Nexus Reconsidered. Review of International Economics, 20(2), 271-87. doi:10.1111/j.14679396.2012.01021.x

Molana, H., Montagna, C., \& Violato, M. (2011). On the Causal Relationship Between Trade-Openness and Government-size: Evidence from OECD Countries. International Journal of Public Policy, 7(4-6), 226-49. doi:10.1504/IJPP.2011.043562

Phillips, P. C., \& Sul, D. (2007). Transition Modeling and Econometric Convergence Tests. Econometrica, 75(6), 1771-1855. doi:10.1111/j.1468-0262.2007.00811.x

Phillips, P. C., \& Sul, D. (2009). Economic Transition and Growth. Journal of Applied Econometrics, 24(7), 1153-85. doi:10.1002/jae.1080

Ram, R. (2009). Openness, Country Size, and Government Size: Additional Evidence from a Large Cross-country Panel. Journal of Public Economics, 93(1-2), 213-18. doi:10.1016/j.jpubeco.2008.04.009

Rodrik, D. (1998). Why Do More Open Economies Have Bigger Governments? Journal of Political Economy, 106(5), 997-1032. doi:10.1086/250038

Ruggie, J. G. (1982). International Regimes, Transactions, and Change: Embedded Liberalism in the Postwar Economic Order. International Organization, 36(2), 379-415. doi:10.1017/S0020818300018993

Sabra, M. M. (2016). Government Size, Country Size, Openness and Economic Growth in Selected MENA Countries. International Journal of Business and Economic Sciences Applied Research (IJBESAR), 9(1), 39-45.

Turan, T., \& Karakaş, M. (2016). The Effect of Trade Openness and Income on the Size of a Government. Transylvanian Review of Administrative Sciences, 12(47), 164-78.

Virén, M. (2005). Government Size and Output Volatility: Is There a Relationship? (Discussion Paper No. 8/2005). Bank of Finland. doi:10.2139/ssrn.782604

Walter, S. (2010). Globalization and the Welfare State: Testing the Microfoundations of the Compensation Hypothesis. International Studies Quarterly, 54 (2), 403-26. doi:10.1111/j.1468-2478.2010.00593.x

World Bank. (2020). World Development Indicators (WDI). https ://databank. worldbank . org/data/reports . aspx?source=world-development-indicators. 


\section{Appendix: Additional Tables}

Table A.1: Country Classifications

Club 1, 48 Members

Algeria, Australia, Austria, Belgium, Bolivia, Brazil, Canada, Chile, Colombia, Costa Rica, Denmark, Dominican Republic, Ecuador, Finland, France, Germany, Greece, Guatemala, Guyana, Hong Kong SAR, Iceland, Israel, Italy, Japan, Korea Rep., Madagascar, Malta, Mexico, Morocco, Netherlands, New Zealand, Niger, Norway, Paraguay, Peru, Portugal, Rwanda, Saudi Arabia, South Africa, Spain, Sweden, Thailand, Togo, Tunisia, Turkey, United Kingdom, United States, Uruguay

Note: The coefficient of log t-test result and its standard error are -0.0521 and 0.0166 , respectively. The $\mathrm{t}$-statistics of the coefficient is -3.1438 .

Table A.2: Summary of the Literature

\begin{tabular}{|c|c|c|c|c|}
\hline Focus & Study & Period/Sample & Method & $\begin{array}{l}\text { Country Classifi- } \\
\text { cation }\end{array}$ \\
\hline $\begin{array}{l}\text { (a) Compensation } \\
\text { Hypothesis }\end{array}$ & 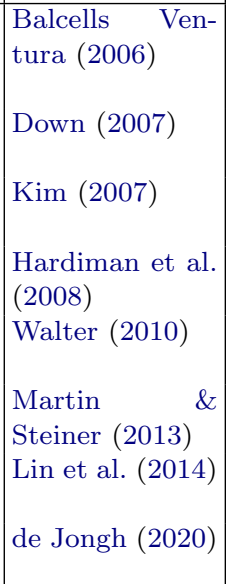 & 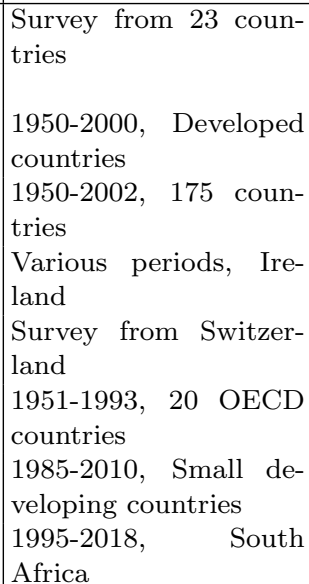 & $\begin{array}{l}\text { Panel } \\
\text { Panel } \\
\text { Comparative } \\
\text { analysis } \\
\text { Logit } \\
\text { Panel } \\
\text { Panel } \\
\text { ARDL }\end{array}$ & 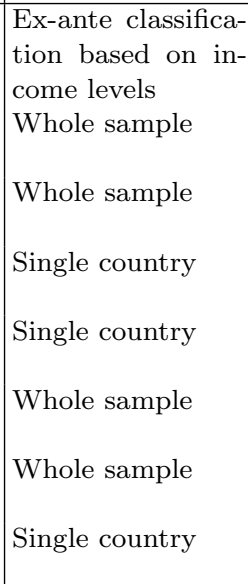 \\
\hline $\begin{array}{l}\text { (b) Efficiency } \\
\text { Hypothesis }\end{array}$ & \begin{tabular}{|l} 
Kittel \& Win- \\
ner $(2005)$ \\
Gemmell et al. \\
$(2008)$ \\
Kim (2009) \\
Leibrecht et al. \\
$(2011)$ \\
\\
Meinhard \& Po- \\
trafke (2012)
\end{tabular} & 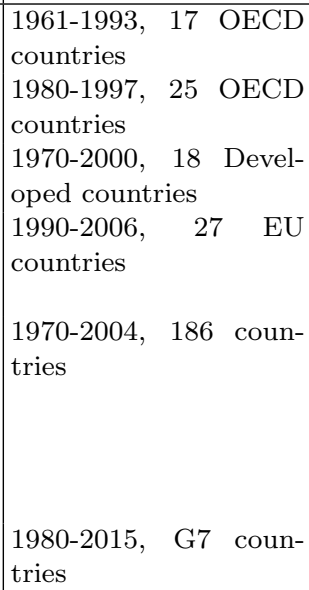 & $\begin{array}{l}\text { Panel } \\
\text { Panel } \\
\text { Auto- } \\
\text { regression } \\
\text { Panel } \\
\text { Panel }\end{array}$ & $\begin{array}{l}\text { Whole sample } \\
\text { Whole sample } \\
\text { Whole sample } \\
\text { Ex-ante classifica- } \\
\text { tion based on wel- } \\
\text { fare regimes } \\
\text { Ex-ante classifica- } \\
\text { tions based on; (i) } \\
\text { OECD and non- } \\
\text { OECD; (ii) before } \\
\text { and after 1990; } \\
\text { (iii) income levels } \\
\text { Whole sample }\end{array}$ \\
\hline
\end{tabular}

